\title{
A Sustained Presence : Synagogue Buildings in Galilee during the Early Islamic Period and Later
}

\section{Bonnie, Rick}

2021-08

Bonnie, R 2021 , ' A Sustained Presence : Synagogue Buildings in Galilee during the Early Islamic Period and Later ' , Journal of Eastern Mediterranean Archaeology and Heritage Studies , vol. 9 , no. 3 , pp. 278-298 . https://doi.org/10.5325/jeasmedarcherstu.9.3.0278

http://hdl.handle.net/10138/338402

https://doi.org/10.5325/jeasmedarcherstu.9.3.0278

unspecified

acceptedVersion

Downloaded from Helda, University of Helsinki institutional repository.

This is an electronic reprint of the original article.

This reprint may differ from the original in pagination and typographic detail.

Please cite the original version. 


\title{
A Sustained Presence: \\ Synagogue Buildings in Galilee during the early Islamic Period and Later
}

\author{
Rick Bonnie \\ University of Helsinki \\ Centre of Excellence in Ancient Near Eastern Empires \\ Fabianinkatu 24a, 00014 Helsinki, Finland \\ rick.bonnie@helsinki.fi
}

\section{Author biography (200 words)}

Rick Bonnie ( $\mathrm{PhD}$, Universtiy of Leuven) is University Researcher in the Department of Cultures at the University of Helsinki, and associated as a vice-team leader to the Centre of Excellence in Ancient Near Eastern Empires. In addition, he currently directs a research project on the impact of climatic changes on the rise and fall of Jewish ritual purification baths in early Roman Palestine, as well as a Finnish Cultural Foundation project that digitizes ancient Middle Eastern objects in Finnish museum collections. Bonnie is the author of Being Jewish in Galilee, 100-200 CE: An Archaeological Study (Brepols, 2019) and a co-editor of The Synagogue in Ancient Palestine: Current Issues and Emerging Trends (Vandenhoeck \& Ruprecht, 2020).

\footnotetext{
Abstract

The majority of archaeological studies on late antique monumental synagogues focus their discussion on the origin and production of these buildings, their decoration, and their use. How these buildings were used, experienced, and remembered in subsequent periods remains little explored. Following a building biography approach, this article aims to explore how the
} 
building remains of synagogues in Galilee persisted into the early Islamic period and beyond, and what the physical state of these monuments and the small finds found within them tell us about how later communities used, viewed, and remembered these spaces. The article explores the remains of several synagogue sites in eastern Galilee using archaeological data, medieval Muslim and Jewish traveler accounts, and early modern depictions of ruins.

\section{Keywords (5-7 words)}

Synagogues, early Islamic Galilee, Building biographies, Ruination, Jewish-Muslim cultural relations

\section{Introduction}

Monumental buildings often outlive their creators, their associated institutions, and their socio-cultural origins. In fact, the lives of buildings, even those built thousands of years ago, can continue almost indefinitely. ${ }^{1}$ The examples I want to touch upon in this article are the monumental synagogues that have dotted the landscape of Galilee, northern Israel, ever since late antiquity. When European and North American travelers started to explore the "Holy Land" in the eighteenth and nineteenth centuries they often stumbled upon the ruined remains of these large edifices. However, notwithstanding their-and our-encounters with these ancient monuments, scholarship discussing the functioning and role of these buildings has prioritized their supposed "main phases" of occupation. By this I mean the period in which these synagogues were first erected, during the third to sixth centuries CE. ${ }^{2}$ Little emphasis

\footnotetext{
${ }^{1}$ For examples, see Bender 1998 on Stonehenge, Watkin 2009 on the Roman Forum, Grabar and Kedar 2009 on the Haram esh-Sharif/Temple Mount, or Yalouri 2001 on the Acropolis.

${ }^{2}$ There is an ongoing debate around the exact dating of these synagogues' construction. For a brief overview with further references, see Hakola, Bonnie, and Tervahauta 2020: 8-10. See also further below.
} 
has been placed on the evidence for the reuse, alterations, ruinations, and appropriations of these synagogue spaces in Galilee, notably for the period of the seventh century and later.

In 636 the commander Shurahbil b. Hasanah took over control of Tiberias, the largest city of that time in eastern Galilee (Fig. 1); or at least this is the conquest narrative as recorded in traditional historical accounts. Once the new Islamic administration became established in the wider region, the city, then known as al-Tabariyyah, became the capital of the new district of Jund al-Urdunn, thereby replacing the former regional capital of Scythopolis. The city flourished during the subsequent centuries due to its administrative position and its industries (on Tiberias, see Avni 2014: 71-88; Cytryn-Silverman 2015). In its hinterland, both to its north and south, large agricultural estates developed during this period, notably the residential complexes discovered at Khirbet Minya and Sinnabra (Avni 2014: 9092). Galilee's landscape during the Umayyad, Abbasid, and Fatimid periods, however, was no blank slate. The region was marked with well-established towns and villages, with Jewish populations and monumental synagogues concentrated around northeastern Galilee. ${ }^{3}$

This article aims to explore to what extent these ancient synagogues continued to live on, and how people built new relationships with these buildings during the early Islamic period and beyond, whether as synagogue, for new functions, or as ruins. It will do so using case studies from Capernaum, Meiron, Meroth, Arbel, Huqoq, Nabratein, and Gush Halav (Fig. 1) that will be explored through a three-step approach focusing on the life histories, memories, and ruination of the synagogues. The aim is to advance discussions on ancient synagogues beyond ideas of the "authentic" value of these buildings, often associated with

\footnotetext{
${ }^{3}$ Based on patterns observed in survey evidence from eastern Galilee, Leibner (2009b) has suggested that Jewish settlements and population were in decline in that region during late antiquity. These conclusions have been critiqued and reviewed recently based on the dating and interpretation of the pottery (Magness and Schindler 2015) and on the employed statistical methodology (Lapin 2017).
} 
their genesis in a largely Jewish-Christian landscape, and instead to highlight the fluid nature of the functioning and meaning of these buildings. The revised approach put forward here, of viewing the synagogues as continuously living elements in a landscape, is intended to contribute to our understanding of the history of these buildings and of the region through Islamic and early modern times, as well as to challenge the repeated characterizations of Jewish-Muslim relationships as inherently antagonistic.

(Insert Figure 1 around here)

\section{Ancient synagogues in the post-Byzantine world}

Ever since the late nineteenth century the building remains of ancient monumental synagogues in Galilee have captured the interest of Western travelers and scholars alike (see, e.g., Kohl and Watzinger 1916; Levine 2005; Hachlili 2013; Bonnie, Hakola and Tervahauta 2020). Intensive excavations have shown that Galilee, most notably along its eastern front, was dotted with monumental stone synagogues that were erected sometime in the third to sixth centuries CE. ${ }^{4}$ The archaeology of these monumental religious gathering sites has been primarily concerned with their genesis and original socio-religious functioning within the Jewish-Christian landscape of Byzantine-period Galilee. For decades now, scholars have been fiercely debating over architectural and artistic styles, stratigraphic finds, and culturehistorical contexts in order to determine when precisely the synagogue first developed and spread across the region's towns and villages (e.g., papers in Avery-Peck and Neusner 2001). Equally lively have been the discussions on the artistic programs depicted on the floor

\footnotetext{
${ }^{4}$ Before late antiquity we have evidence of only a few monumental synagogues in the region, primarily attributed to the early Roman period. See Aviam 2019: 298-99. How this institution developed during the subsequent middle Roman period has received growing attention in recent years. See Bonnie 2019: chap. 7.
} 
mosaics and other architectural features in these synagogues, their artistic influences, and their socio-religious connotations (Levine 2013; Hachlili 2013: 223-538). These debates have been important to understanding how late antique Jewish life in Galilee developed and was impacted by Byzantine Imperial culture. Only more recently, especially in the work of Karen Stern, have aspects of the later viewing and use of synagogue art, beyond the artist's original intent, as well as of that of the synagogue spaces in their entirety, been given further thought (see esp. Stern 2016; 2018; 2019; 2020).

The same can be said for how these synagogue buildings were viewed and used beyond the Byzantine period. For example, in his otherwise excellent overview of the ancient synagogue, Lee Levine merely spends a single sentence suggesting what happened during the early Islamic period: "It was only the Moslem conquest, with its far-reaching political, social, and economic consequences, that effectively began to constrict local Jewish life, one of the indications of which was the precipitous decline in the number of synagogues throughout the country" (Levine 2005: 249). In a recently published online catalogue of known ancient synagogues in the region, none of the listed synagogues are attributed dates later than the Byzantine period, even if such sites show evidence of continuing occupation. ${ }^{5}$ Such views can contribute to the sustained ideas of adversarial Jewish-Muslim relationships in the past.

By privileging these monuments' Roman-Byzantine conceptions as synagogues over other parts of their life-histories, scholars and heritage authorities have shaped a narrative of identity and use for the present and future that is essentially in stasis (e.g., Harvey 2003; Hamilakis 2007; Holtorf 2015). Thus, conventional synagogue narratives were introduced to strengthen existing ideas of a strong cultural break between Byzantine and early Islamic societies (for discussion, see Avni 2014: 11-39). For example, when the historian Moshe Gil

\footnotetext{
${ }^{5}$ See http://synagogues.kinneret.ac.il.
} 
argued for a "local population [suffering] immensely during the course of the [conquest]," he enhanced it by suggesting that "[this] period [...] was also that of the destruction of synagogues and churches of the Byzantine era" (Gil 1992: 61). There is in fact little evidence for such conquest-like destruction events, including conflagrations, found in the dozens of synagogue excavations across the region. Instead, when a collapse did occur around that time period, the final collapse was usually assigned to natural causes, primarily earthquakes. The most notable of these was the earthquake of $749 \mathrm{CE}$, when the region was already long under Islamic occupation. However, as there has been a lack of interest and debate on the lives of synagogues beyond their original period of functioning, this silence has made room for alternative suggestions, such as conquests, to thrive.

More recent studies on settlement dynamics during the Byzantine-early Islamic periods have shown that this transition was far more gradual, and that Galilean towns and villages continued to be occupied (Magness 2003; Avni 2014; Walmsley 2007; Taxel 2018; Leibner 2009a: 384-89). While this has implications for our view on monumental synagogues as well, discussion of that evidence has remained in the margins. Alan Walmsley (2007: 78), as part of his argument for urban renewal, makes note of evidence for early Islamic renovation work in two excavated synagogues at Tiberias. Gideon Avni's study makes more extensive use of the archaeological evidence for synagogues, primarily to substantiate his argument of settlement continuity into the eighth and ninth centuries (see esp. Avni 2014: 212-17). Jodi Magness has addressed the continued use of synagogues in Galilee into the early Islamic period most extensively. She did so by focusing and re-evaluating the chronologies of single synagogue sites (Magness 2001; 2010; Magness et al. 2018).

In all these works the discussion centers around whether synagogues continued in use through parts of the early Islamic period, where use signifies its primary function, and when precisely the building was abandoned. In this article my interest is more on how these 
monumental synagogue spaces in their post-Byzantine setting still shaped the landscape, including the lives of the people living there. The physical nature of the building itself, whether in ruins or not, is of less concern than its continuing societal role.

\section{Studying the protracted biographies of synagogues}

The fact that the protracted biographies of these monumental synagogues are not frequently addressed relates to broader discussions of priorities in archaeology in general. A major issue that complicates matters is our arbitrary division of periods (e.g., Roman, Byzantine, Islamic), the use of these periodizations in making archaeological typologies, and the associated narrow specializations of historians and archaeologists that comes with it (see also Avni 2014: 31-35; Bernbeck 2019: 5). The rise of the field of late antiquity studies during the 1990s has helped to blur these arbitrary chronological boundaries, and has provided new conceptual tools to explore, for instance, the continuities of Byzantium into the Arab-Islamic culture (Evans and Ratliff 2012).

The exclusion of earlier-built synagogues from views of the early Islamic landscape and onwards, however, is notably caused by scholars' tendency to focus only on those sites, structures, and artefacts that were produced during this period. The usual temporal adjective used for synagogue buildings, whether "late antique," "late Roman," or "Byzantine," emphasizes their state of production, thereby prioritizing a kind of original cultural landscape in which they stood. Their original meaning is somehow seen as more authentic. Such “insistence on this temporal attribution," as Hamilakis (2013: 123) pointed out, "is not unrelated to their position within national imagination, as well as Western imaginary as a whole."

The meaning of ancient monuments is not intrinsic, but is continuously in flux as a result of their functioning in their wider cultural surroundings. As decades of archaeological 
discussions of time, object biographies, and the archaeological record has shown (Kopytoff 1986; Gosden and Marshall 1999; Pluciennik 1999; Lucas 2005; 2008; 2016), sites, buildings, and artefacts did not carry any particular authentic meaning but changed over time. The fact that buildings and sites persist in time and cross our arbitrarily separated periods, whether in a functional state or in ruins, and act as mnemonic devices for those living in the future has in recent years been widely recognized (see, e.g., Olivier 2004; 2008; Jones 2007; Lucas 2016: 107). They form a kind of palimpsest, as Geoff Bailey (2007: 207-8) has termed it, in which an object, building, or site acquires a succession of meanings as a result of different uses and associations throughout time.

I am interested here in how different contexts, periods, and ways of viewing allow synagogue spaces to take on new meanings and functions, perhaps different from their originally intended ones. The lives of buildings are very much the product of valuation and interpretation by contemporaries. Without their presence in modern life, as found in excavations or as heritage sites, they would not have a known original production in the past to begin with (Holtorf 2002). The itineraries of these buildings - the people, cultures, and natural events they encounter- differ case by case throughout time (see Joyce and Gillespie 2015).

But how to study the later stages of the itinerary of different monumental synagogues in Galilee? Reconstructing building biographies, especially their intermediate stages, is known to be difficult. Often archaeologists are left with evidence of their construction and different subsequent building stages, yet usually without many associated artefacts from which to deduce the use of spaces. These artefacts are primarily associated with the buildings' final stage before destruction, which provides evidence for their final use before collapse (for discussion, see Joy 2009: 543; Lucas 2016: 105-8). The use phases prior to final use, or those after a building's initial collapse, are often more difficult to understand. 
Here I will attempt to tackle this problem by emphasizing three different ways of viewing these monuments. A more conventional archaeological life history gaze focuses on the material evidence for the early Islamic uses as suggested from excavation reports. Careful excavations and reappraisals of that evidence over the last decades, notably thanks to Magness' work, have shown that quite a number of these synagogues remained in use into the seventh and eighth centuries (Magness 2001: 35-36). A historical memory gaze discusses references to and omissions of these sites in medieval Muslim and Jewish traveler accounts. While most of these accounts are from the tenth century and later, they still provide insights into how locals and travelers alike came across and understood these monuments. Finally, I explore an early modern ruins gaze, primarily developed from pictorial and photographic accounts of western viewings of these monuments during the nineteenth century. It focuses on the durability of the monuments far beyond their Byzantine origins. Instead of an Orientalist trope of viewing these ruins as "mere emblems of cultural decay," I use their notunscathed appearances to give voice to "their long-standing role as essential elements" in the landscape (Halevy 2018: 53).

\section{Synagogue ruins among village communities}

In the center of Capernaum, situated on the northern shore of the Sea of Galilee, lies the most iconic of late antique monumental synagogues. ${ }^{6}$ Within the heart of the ancient town, surrounded by traditional houses built from local dark basalt, stood a monumental public building, built on basalt foundations and an artificial platform, erected from neatly hewn

\footnotetext{
${ }^{6}$ The Capernaum synagogue has been considered the most iconic of the so-called "Galilean-type" of synagogues. As such, it has been at the forefront of a decades old discussion on when this synagogue (and this particular type) was constructed (see Magness 2001; Tarkhanova 2020). Although discussions still continue, most scholars agree that this white monumental building was constructed sometime between the second half of the fourth to sixth centuries.
} 
white limestone ashlars quarried from the surrounding areas, with a pitched roof and roof tiles (Fig. 2) (for details, see Corbo 1975: 113-69; Loffreda 1985: 32-49; Magness 2001: 1826). Three double-door entrances led from the south directly into a large interior hall, surrounded by a colonnade with highly decorated friezes along three sides. An entrance to the east led to a large porticoed courtyard, which was also accessible directly from the outside through a variety of entrances.

(Insert Figure 2 around here)

What interests us here is the building's final stages as a synagogue. Aside from two dedicatory inscriptions carved into two of the synagogue's columns, the dates of which are disputed (Hachlili 2013: 62-63), the figurative stone reliefs found inside the synagogue were also subject to iconoclasm in the later stages of its functioning. It is generally agreed that this iconoclasm, notable because of its careful treatment of other art inside the synagogue, was the work of a Jewish group (Schick 1995: 202; Yuval-Hacham 2014: 37-38 n. 26). Noa YuvalHacham furthermore argued that this iconoclasm occurred under Umayyad reign, during the seventh to eighth centuries (Yuval-Hacham 2014: 38-39). This modification ultimately speaks to the changing nature of Capernaum's Jewish community, which now disapproved of such imagery inside synagogues, but still experienced the sanctity of the space and used it as such.

The severe earthquake of $749 \mathrm{CE}$, which damaged large cities and towns across the region (Tsafrir and Foerster 1992; Cytryn-Silverman 2015; Rattenborg and Blanke 2017), would have likely damaged structures at Capernaum and other regional synagogue sites. However, the last stages of the Capernaum synagogue are difficult to reconstruct. In part this is due to the lengthy nature of investigations at the site, through which different excavation 
and restoration campaigns since the late nineteenth century have effectively cleared out most deposits situated above floor level. The excavators suggested that the synagogue continued in use until at least the early Islamic period. This is based on certain direct and indirect stratigraphic indications, including evidence of a small hoard of gold coins, the latest of which is dateable to $668 \mathrm{CE}$ at the latest, found within the synagogue (Corbo 1975: 169; see Callegher 1997 for the coin hoard).

Based on seventh- and eighth-century numismatic and ceramic finds found beneath surface levels at several spots in and around the synagogue, Magness has tentatively suggested that the Capernaum synagogue underwent repairs in the second half of the eighth century or later (Magness 2001: 36). ${ }^{7}$ These types of repairs, if correct, would suggest that the space still continued to be valued and in use for some time during the Abbasid period. This appears to be supported by evidence of several gaming boards that were engraved on paving stones in the eastern courtyard, stylobates, and within the synagogue itself (Corbo 1975: 169; Loffreda 1985: 40). ${ }^{8}$ These indications from the Capernaum synagogue demonstrate the functioning of the building as an active social space within its community, and concurs with emerging evidence, notably from Jerash, of the resilience of communities in the aftermath of the severe 749-earthquake (Rattenborg and Blanke 2017). Although the identity of the users of this space cannot be established without a doubt, this may also provide a material

\footnotetext{
${ }^{7}$ Magness (2001: 36) also lists a Tulunid coin from the second half of the ninth century, found between synagogue paving stones, first noted in (Spijkerman 1975: 43, n. 346). For reasons not entirely clear, this coin is not included in Capernaum's recent coin catalogue (Callegher 2007).

${ }^{8}$ Similar types of gaming boards have been found in the baths of Hammath Gader (Amitai-Preiss 1997: 27677), the synagogue at Qasrin (Hachlili 2013: 99, table III-1, no. 129), and the residence at Horvat 'Aqav (Sebanne 2000). Contrary to what the excavators at Capernaum believe, these engraved gaming boards do not $a$ priori exclude the building's functioning as synagogue space. Moreover, it should be noted that, based on archaeological context, an earlier Byzantine date cannot be ruled out for the engraved gaming boards at Capernaum.
} 
indication that the strict rulings in the Abbasid period regarding the dhimmin (non-Muslim) population were, at least at times, not enforced in practice (for discussion on these rulings and their enforcement, see Levy-Rubin 2011: 99-112; Sirry 2011).

This evidence hints to the fact that people living in the synagogue's surroundings still, at that time, used the synagogue space. Indeed, there is strong evidence from the basalt houses surrounding the synagogue and from structures uncovered in the adjacent plot of the Greek Orthodox church that Capernaum continued to function as a village throughout the early Islamic period (Tzaferis 1989; Magness 1997). A lack of later archaeological remains suggests that it was abandoned by the eleventh century. Whether at that time the synagogue was still in use seems unlikely, based on an absence of artefacts from that area later than the ninth century. Evidence of ornamented fragments reused as spolia in the construction of houses (Loffreda 1993: 294) furthermore suggests that the synagogue was slowly being dismantled and disentangled from Capernaum's village community. The exact reasons for this remain unknown. However, while being in an advanced state of ruination and decay, the sheer physicality of the synagogue's limestone remains within the village surroundings surely evoked memories and stories among those who continued to live in its shadows.

Capernaum was not the only synagogue that had a continuing physical presence among the early Islamic village communities. Further up north, in the shadows of Mount Meiron, the late Roman-Byzantine synagogue of Meiron continued to exert its presence in a similar way, even if not actually in use (See Meyers, Strange and Meyers 1981; Spigel 2012: 113-15). The synagogue was built on top of a terraced hill slope, with its western wall built into the slope. Accessed from a tri-portal entrance in the south, the synagogue consisted of a large gathering hall with a U-shaped colonnade. Although the building has been difficult to date, its excavators have suggested that it was erected around the mid-third century CE and lasted until the late fourth century, when different causes led the village to be largely 
abandoned. In the centuries that followed, sparse evidence of material culture and crude wall constructions suggest that the village of Meiron was only irregularly occupied and visited.

During the eighth century, however, the village was reoccupied permanently and new buildings were erected (Meyers, Strange and Meyers 1981: xix-xx). Although the excavators exposed glimpses of this Umayyad and Abbasid village life, most remains of this period are apparently found beneath modern buildings to the south-east of the abandoned synagogue. The village seems to have thrived at least up to the thirteenth century and beyond (Smithline 2015). What's more, despite the long occupational gap between the fourth and eighth centuries, the synagogue's tri-portal south-facing facade continued to withhold decay. Nineteenth-century photographs (Fig. 3) show the monumental façade as still standing. It is reasonable to assume that it remained a significant visual element for late antique visitors and the village community from the eighth century onwards.

(Insert Figure 3 around here)

How villagers and others used and experienced the standing ruins of this synagogue remains unclear, but, as in the case of Capernaum, the fact that it continued to be preserved over the centuries is an indicative factor of its significance. This probably had something to do with Meiron's recognition as the place of the burial cave of the tannaitic sage R. Simeon bar Yochai, his son, and other prominent rabbis, which led to the village's development into a well-recognized pilgrimage site (Meyers, Strange and Meyers 1981: 4-6).

Early literary attestations of its functioning as pilgrimage site come as early as the twelfth century, and these attestations may also have alluded to the presence of a ruined synagogue. For example, the later twelfth-century itinerary of Jacob ben Nathanael ha-Kohen noted that, in addition to the burials, Bar Yochai's "College is still standing" (Adler 1930: 94). The later traveler Samuel ben Samson (d. 1210) saw, in addition to the tombs, "a very 
fine synagogue" (Adler 1930: 108; see also Kohl and Watzinger 1916: 80). Whether any of these were in fact observations of the still standing facade of the synagogue, or refer to other—possibly imaginary—-places cannot be known for certain. ${ }^{9}$

The pilgrimage site of Meiron was visited by both the Jews and Muslims living in the area, including worship that took place in the cave, as is attested by contemporary textual accounts, including the Muslim qadi (magistrate or judge) al-'Uthmani and the Arab geographer al-Dimashqi (Khalidi 1992: 476-77; Meri 2002: 242-50; Yazbak 2010: 233). As al-'Uthmani wrote:

"Mīrūn contains waterwheels and pools in a cave from which water trickles. On an appointed day of the year on the fifteenth of the month of Ayyār of the Jews (Passover) a great gathering of Jews would congregate there from near and faraway lands. They dug their canal around that place. Water flows out into that canal more than is customary. Jews take that water to distant lands.” (transl. Meri 2002: 247; for original, see Lewis 1953: 480)

A Jewish resident, Daniel, described it in $1473 \mathrm{CE}$ to an anonymous traveler from Crete as follows:

\begin{abstract}
"Another cave, in which R. Shim'on b. Yohai is buried, contains no running water, such that people cannot live there from its paucity. However, the Jews go there on the three festivals to see the tombs of the important aforementioned zaddiqim, especially that of R. Shim'on b.

Yohai. They supplicate with penitential prayers and prayers of supplication to God, blessed be
\end{abstract}

\footnotetext{
${ }^{9}$ These medieval itineraries primarily focused on the presumed burial locations of well-known rabbis from the past, i.e. "the tombs of their ancestors on account of which the world exists" (Jacobs 2014: 26). Other building remains were in most cases ignored, although whether this was because they were not deemed important or were not identified as such remains unknown.
} 
$\mathrm{He}$, that He grant them water so that they may be able to remain there, and another source of water. The rains then immediately fall and the Muslims fill their wells and vessels. Then the Muslims give the Jews food and drink, all the delicacies befitting a king." (transl. Meri 2002: 249)

Many of these pilgrims surely would have seen the still standing remains of the earlier monumental synagogue, and new narratives and memories were thus instilled in this building. While the village seemed to have continued to thrive, with a population of 715 noted in the late sixteenth century (Khalidi 1992: 477), its Jewish community may have become smaller or even non-existent (Smithline 2015: 140). It may be that these new memories about the site and its history were preserved among Meiron's community, which ultimately allowed the synagogue's façade to be preserved. In fact, Edward Atkinson noted in 1859 that after the 1837 earthquake Meiron's community actively made an effort to rebuild and preserve the facade (Atkinson 1878: 25; see also Robinson 1856). Bar'am, a former Christian Maronite hilltop village in northern Upper Galilee, is another site where synagogue ruins were standing several meters high into the nineteenth century. The ruins of the larger of two preserved synagogues formed part of Bar'am's townscape, and was partly modified and reused as a farm shed in the nineteenth century (Fig. 4) (see Bonar and M'Cheyne 1849: 269-71; van de Velde 1854: 175-77; Robinson 1856: 68-71; Thomson 1860: 282).

(Insert Figure 4 around here)

This continuing survival of and connection to the Meiron synagogue remnants contrasts with what happened at Capernaum (Figs 5-7). There, when the village surrounding the synagogue ruins was abandoned, no one took the effort to preserve these remains. The 
site seems to have gone unmentioned in any of the medieval traveler accounts. When European and American travelers of the eighteenth and nineteenth centuries searched for this place and asked about it from locals, they did show a familiarity with its ruins, though mostly as a source of building material (Pococke 1743: 71-72). As Wilson wrote, "but the peasants knew that even underneath this there was material, marble and limestone, which they could convert into lime" (Wilson 1881: 84; on lime production in Galilee, see Bonnie 2016). The site was not settled anymore, and instead the local occupation seems to have shifted over time to the Bedouin village of al-Samakiyya (Khalidi 1992: 538-39). The lack of local memories about this place was perhaps the cause for the earliest travelers to misidentify its remains as that of a church.

(Insert Figures 5, 6, and 7 around here)

\section{The lingering functionality of synagogue buildings}

Archaeological research unfortunately has not always given due emphasis to the village surroundings in which monumental synagogues were set. Evidence from sites other than Capernaum and Meiron, however, demonstrate that in other villages their synagogues either remained functioning, had their functioning revived, or even changed their functioning drastically.

The monumental synagogue at Meroth, in the northernmost extent of upper Galilee, shows continuing functioning and renovation work up into the thirteenth century (Ilan and Damati 1989; Ilan and Izdarechet 1993; Hachlili 2013: 69-72). The building was erected in the first half of the fifth century as a large rectangular gathering hall with a closed-off courtyard along its southern and eastern sides. The gathering hall could be accessed from the south via three doors. Inside, the hall was divided by two rows of columns, and stone benches 
were situated along the western and eastern walls, as well as along part of the northern wall. Later, in the second half of the fifth century, the internal plaster floor was replaced by a figurative mosaic floor, probably representing a Helios-and-zodiac motif. During the sixth century, more extensive renovations were carried out to the synagogue plan.

Further extensive renovations were undertaken during the seventh and eighth centuries, probably in part due to earthquake damage. The most notable is the rebuilding of the synagogue's northern exterior wall, which was moved slightly inwards and, with three entrances, now functioned as the building's main entrance. This shift in orientation and access route may have been a necessary consequence of social, cultural, or merely structural changes in the surrounding village, which has remained mostly unexposed. The excavators maintain that the building during this phase became a larger communal center with several functions, including that of a school and midrash (i.e., Jewish study center). The latest evidence of a coin deposit below a storeroom's floor, dating to $1193 \mathrm{CE}$, suggests that the building was abandoned sometime in the thirteenth century.

Moving to the south, along the northeast area of the Sea of Galilee, built high up on the cliffs of Mount Arbel, lies the monumental synagogue of Arbel (see Kohl and Watzinger 1916: 59-70; Ilan and Izdarechet 1993; Hachlili 2013: 59-60; Arubas forthcoming). ${ }^{10}$ In its initial construction phase, around the fourth century, the synagogue consisted of a large gathering hall with an U-shaped colonnade and rows of stone benches running along its western, northern, and eastern sides. Its main entrance was from the east, with a possible second but smaller entryway from the west. Several centuries later, during the sixth to mid-

\footnotetext{
10 The site has received scant archaeological investigation ever since Kohl and Watzinger's visit in 1905. Since 2012, Benjamin Arubas has renewed investigations of the synagogue and has revised considerably the chronology of the building, extending it up to the thirteenth-fourteenth century CE. See (Arubas, forthcoming). I thank Dr. Arubas for discussing the unpublished provisional results of his investigations.
} 
eighth centuries, the synagogue underwent extensive renovations, and may even have been largely rebuilt from the ground up. The building received a new main entrance that was set centrally in the northern exterior wall. Opposite it, in the south wall, a semicircular niche was added to the building (Fig. 8).

(Insert Figure 8 around here)

Early visitors to the site, as well as the original excavators Kohl and Watzinger (1916: 63), argued that the added semicircular niche was a late addition and functioned as a mihrāa, a prayer niche facing Mecca, thereby altering the building's function to that of a mosque. This claim was refuted by Avigad, who, based on a few soundings, suggested that the niche's three lowest courses were original to the building and were thus laid before the Islamic period (Avigad 1967: 98-100, Fig. 5; discussed in Hachlili 2013: 60). Avigad and subsequent scholars (Ilan and Izdarechet 1993: 88-89), therefore, refuted Kohl and Watzinger's idea that Arbel's synagogue was later converted into a mosque.

The recent investigations by Arubas, however, have not found evidence to support Avigad's claim and, instead, see stronger indications that the niche was a later addition, dating either to the sixth-seventh centuries or to the eighth-ninth centuries. This raises the possibility that the original suggestion of the niche functioning as a mihrāb may be correct, and that the building was indeed at that time converted into a mosque (see Arubas forthcoming). ${ }^{11}$ What this exactly means for the nature of Arbel's community remains unclear, as preferably pottery and other small finds from floor deposits should be taken into

\footnotetext{
${ }^{11}$ This would be the first synagogue space in Galilee that during the early Islamic period was converted into a mosque. Synagogue-Mosque conversions are better known from southern Palestine, notably from excavations at Khirbet Susiya and Eshtemo'a. For discussion, see (Magness 2003: 100-103; Werlin 2015: 136-200).
} 
consideration as well. There are clear indications from the early Islamic period of a sharing of religious spaces in certain instances, such as in the case of the Kathisma church near Jerusalem, where a mihrāa was found in the southern part of the church (Avner 2006-7: 550; Avni 2014: 150-51). It is interesting to note that by the early thirteenth century the Jewish traveler Samuel ben Samson seemed to have recognized the then-ruined structure as that of a synagogue: "We climbed up to Arbela, where stood the great synagogue which Nittai caused to be built there; it is now, on account of our sins, in ruins" (Adler 1930: 106).

Some ten kilometers to the north of Arbel, on a shallow-sloped hill, lies Huqoq, with evidence for two basilica-shaped monumental synagogues overlying one another. Still ongoing excavations are revealing in detail a long-term occupational presence and adaptation of the site ever since late antiquity (see esp. Magness et al. 2018; 2020). ${ }^{12}$ When the original fifth-century basilica-shaped synagogue eventually fell out of use is not yet clear. The building seems to have been already abandoned prior to its collapse, perhaps due to an earthquake, as a result of which the collapse of its walls and roof damaged part of the mosaic floor (Magness et al. 2018: 88). However, during the late medieval period an even larger monumental building was constructed directly on top of its remains, with a similar orientation, and reusing much of its earlier architectural elements (Magness et al. 2018: 7486).

This later building, currently dated to the fourteenth-fifteenth centuries (Magness et al. 2020; thereby revising 2018), reused the earlier synagogue's eastern and northern walls but was expanded to the south and west. The stylobate and pedestals were lifted from the earlier synagogue and incorporated into the floor of this building, which was a meter higher than that of the earlier synagogue. The late medieval basilica-shaped building had double-

\footnotetext{
${ }^{12}$ The Huqoq synagogue site is primarily known for its unique pictorial program of the well-preserved mosaic floor of its fifth-century synagogue. See, e.g., Magness et al. 2014; Britt and Boustan 2017.
} 
tiered benches running along its outer walls (Magness et al. 2018: 85). While the excavators earlier presumed that this later building was also used as a synagogue (Magness et al. 2018: 85), recent evidence and insights have led them to question this functioning, and other possibilities remain open (Magness et al. 2020).

While we still do not know what happened between the abandonment of the earlier synagogue and the construction of the later one, the fact that much of the earlier foundation and building blocks were reused suggests that its ruined state was visible to people during the early Islamic period. Moreover, as the latter building was erected on the same spot and with the same orientation, this suggests that the site and its functioning was recognized by its surrounding communities. Indeed, the fourteenth-century Jewish topographer Ishtori Haparchi reported a synagogue with a "very old floor" at this site, which may refer to the earlier synagogue being still recognizable in the material features of this later building (Magness et al. 2014: 338-39; see also Lissovsky 2008: 107), even though its function may have been different.

\section{A shifting cultural outlook}

We do not currently have such strong evidence for the longevity of other synagogues and their surroundings as for those discussed above. Notwithstanding this, small finds found in synagogues that reveal some of the final stages of the buildings' use can provide some insights into the changing outlook of their communities. To make this point, I focus here on two well-excavated examples from Upper Galilee.

The synagogue of Nabratein, according to its excavators, was re-founded and considerably enlarged in the sixth century, after which it continued to function as such up to the early eighth century at the latest. They note that this therefore "raises questions about the life of the Jewish community in this remote area of Upper Galilee, which persisted when 
other sites in the region were abandoned" (Meyers and Meyers 2009: 400). More recently, Magness has suggested that this synagogue continued to serve Nabratein's Jewish community throughout the eighth century, after which it was slowly deserted (Magness 2010: 66). Evidence for this reappraisal of the last stages of this synagogue notably comes from the large number of Umayyad coins found inside the building, all minted during the late seventh century in Damascus (Meyers and Meyers 2009: 400; also Magness 2010: 66). The prevalence of these coins within Nabratein's community point to a shift in its population during this period, in terms of its socio-economic orientation; away from Tyre along the Phoenician coast, which was a major economic force during the previous centuries (see, e.g., Hanson 1980; Syon 2015), toward the Syrian inland and the Umayyad capital.

When the synagogue of Gush Halav fell out of use and was abandoned remains a matter of discussion. The excavators argue that the building was destroyed during an earthquake in the mid-sixth century, while Magness has argued that its occupation lasted at least until the late seventh or early eighth century (Meyers, Meyers and Strange 1990; Magness 2001: 3-18; Meyers 2001; see also Spigel 2016). The lack of restorable ceramics and evidence for a conflagration indicates that the building was already abandoned prior to its ultimate collapse (Magness 2001: 17-18; Meyers, Meyers and Strange 1990: 129-30), probably related to the 749 earthquake.

Among the finds attesting to the last stages of the building's use is an intact oil lamp with a partly-preserved incised Kufic-Arabic inscription containing the basmala (Meyers, Meyers and Strange 1990: 129, 164-65). It was found in one of the upper debris layers in the synagogue's western corridor (Magness 2001: 35; cf. Meyers, Meyers and Strange 1990: 49, $72,258)$, several meters away from a later raised podium that has been interpreted as a bema. Some scholars have suggested that this evidence is indicative of a Muslim presence at this stage within the synagogue space (e.g., Magness 2001: 35-36; Nees 2016: 152). However, 
the basmala was also used among Jewish and Christian populations, as attested from medieval letters (Almbladh 2010), and as such it remains impossible to deduce the religious affiliation of its users from this evidence alone. Nevertheless, whoever used this item, the incised oil lamp and its context serve as an indication of the fluidity of confessional boundaries at this time. This should not surprise us so much within the context of late antiquity, as it is alluded to in both literary and material sources elsewhere (e.g., Donner 2010: 194-224; Khalek 2011; Penn 2015; Renard 2020).

After the synagogue's collapse the community of Gush Halav reinhabited the synagogue's space, at some point during the ninth century at the latest. There is no evidence that they attempted to rebuild the old structure, but instead ceramics, including glazed wares, from this period suggest that they lived among its ruins (Magness 2001: 17-18). A limestone gaming board with an Arabic inscription has been attributed to this period of occupation, and suggests that those who lived in the old synagogue space may have used it as a household setting (Meyers, Meyers and Strange 1990: 72) (no further information on the gaming board and its inscription is provided).

\section{Discussion}

The extended narratives of synagogue spaces from Capernaum, Meiron, Meroth, Arbel, Huqoq, Nabratein, and Gush Halav presented above have hopefully shown that in certain instances synagogues in Galilee could continue to function into and even throughout the early Islamic period. We may even speculate from this discussion that the longevity of use of these spaces was not an isolated phenomenon, but something that may be possible to attest at other synagogue sites as well. The reason for why these buildings' life histories are often not discussed in full seems to be rooted in the greater weight that scholars have attached to the genesis and initial stages of usage of the institution of the synagogues. 
The evidence for later modifications, reuses, and repairs of these buildings were perhaps not unnoticed by scholars, but for various reasons less significance and attention has been placed on them. The same could be said for evidence attesting to the reoccupation of synagogue ruins after these buildings' initial collapse. Disciplinary boundaries between those archaeologists and historians studying the Greco-Roman worlds and those studying the later Islamic worlds may certainly play a role. Another cause for this may be the greater interest by those scholars studying ancient synagogues in understanding the relationship between late Second Temple-period Judaism and subsequent developments in Judaism.

The lack of scholarship on the reuse and ruination of synagogue buildings in Galilee has effectively strengthened ideas about the relative cultural stasis among its Jewish communities, supposing that their synagogues continued to function and to be valued by their communities in similar ways for centuries. Few scholars seem to comment upon whether different generations of synagogue-goers would have used these spaces differently from their originally intended uses. These views may have bolstered ideas of cultural antagonism or friction when Galilee shifted into an Islamic cultural landscape by the seventh century.

The provided case studies demonstrate that there is no single narrative of Galilean synagogue life into and throughout the early Islamic period. Each synagogue tells a different story, in line with how the surrounding village or town developed. While the 749 earthquake appears to have had a strong impact on Galilee's synagogue communities, their response to the destruction seems to be diverse. In some communities, such as Capernaum or Meroth, the earthquake damage could be repaired, while in other cases it seems that there were not enough means or needs to do this. However, the synagogue as a monument within the community continued to play a role well beyond the intended ideas of its producers. Thus, at Capernaum the synagogue seems to have been slowly dismantled and its building blocks and space put to new use sometime during the ninth century or later, while its surrounding 
community still lived there, while at Meiron a new village life was started around a single synagogue façade, and at Huqoq decisions were made to reuse the foundations of an older synagogue to build an even larger communal building.

The synagogues also seem to have responded differently to the wider changing cultural environment of the early Islamic period. Nabratein's community slowly shifted in terms of socio-economic networks, which left its marks inside the synagogue. Evidence of engraved gaming boards in and around the Capernaum synagogue may illustrate changes in the social interactions in this space. At Gush Halav it may be speculated that those accessing the synagogue, whether Jews or Muslims, show a blurring of confessional and cultural boundaries in terms of behavioral and material practices. Finally, at Arbel the current evidence suggests that its community eventually consciously decided to convert the synagogue space into that of a mosque. The fact that the building's southwards orientation faced both Jerusalem and Mecca may not only have led to doubt among earlier scholars with regard to the building's identification, it also made the necessary architectural changes rather subtle. With little information from pottery, small finds, and other features from floor level deposits for us to go on, perhaps we should not be too surprised if the subtle architectural changes in the space may have blurred the functioning of this particular space for users and visitors alike.

Indeed, what comprised a "Muslim," "Jewish," or in fact "Christian" space in this period remains hard to answer. In order to provide identifications, archaeologists and historians often reverted back to simple architectural typologies, more general textual source evidence, and broad assumptions about a particular community's religious makeup. Along with the aforementioned lack of attention to the post-Byzantine use-lives of synagogue buildings, the static image that such identifications create may be another cause for earlier 
suppositions on Jewish-Muslim antagonistic relationships, as outlined in the beginning of this article.

Communities change and reshape over time, however, and so do their buildings. The lived reality of early Islamic Galilee was undoubtedly much more complex and messier than our evidence allows us to reconstruct. The case study evidence presented here is far from straightforward indeed, allowing others to question and challenge my suggestions and interpretations. Further temporal nuances are needed as well, as the shifting geographies, economies, and politics of consecutive early Islamic dynasties surely changed realities on the ground over time. To further our understanding of these spaces as living elements of local landscapes, more detailed contextual analyses of small finds and features, along with scrutinizing the phases of collapse, dismantlement, and reuse of these building spaces and their architecture is most surely warranted (e.g., Stern 2018; 2020; Magness et al. 2018; 2020).

The diverse and changing nature of early Islamic synagogues, as illustrated in this article, relates well to wider scholarly ideas of more fluid boundaries between Jewish, Christian, and Muslim identities during this transition phase, if not also later. It compares with material and textual evidence of the blurring of spatial boundaries - notably between Muslims and Christians_-from such areas as Rusafa (Penn 2015: 144-45) and the Jerusalem region (Avni 2014: 158).

This brings me to the necessity of complicating the notion of abandonment phases in synagogue spaces and what happened to them afterwards. In a recent article on "squatter occupation" in Iron Age Median sites, Reinhard Bernbeck (2019) shows how archaeologists' terminology of phases directly affects the way they conceive spatial hierarchies. By using chronological hierarchies such as "main phase," "abandonment," and "squatter occupation," archaeologists give value to the conceived space over that of the lived reality. To put this into 
our context, the terminology prioritizes the intended function of synagogue space by builders and benefactors as authentic and thereby degrades any other usage or experience of that space. Yet, for those later users of this space, their ways of using this synagogue space was the authentic means of performance.

The new appropriation of this existing synagogue space by later users, following Bernbeck, should tell us something about the tensions and different interests between different groups over the social production of that space. By examining and prioritizing those later stages of built space, it is hoped that this article has revealed somewhat the different tensions and interests at play in the production of space in these monumental synagogues during the early Islamic period and beyond. These synagogues were not simply constructed, used, and abandoned. Their modifications and transformations, as well as ruinations, can tell us something about the negotiations that happened within communities about these spaces.

In fact, where do we draw the line demarking the effective end of Galilee's ancient synagogue buildings? In several of the case studies presented, parts of the building were still standing when the first Western travelers arrived in the region and still are, even sometimes restored, up to today. In other cases archaeologists have carefully excavated through younger layers in order to document and re-expose these ancient synagogue remains. Based on the scholarly, cultural, and artistic valuations of today, their remains are either prepared as heritage sites and/or taken into museums. Galilee's ancient synagogues, one may conclude, are still with us today as living elements of a landscape. Thus, the manner in which archaeologists and heritage practitioners engage with these buildings shapes their functioning for the past, present, and future, whether religious, cultural, political, or economic. Their present state is simply a passing phase in these buildings' biographies, but the manner through which archaeologists and heritage practitioners shape this phase has a direct consequence on today's lived realities and communal relationships in the region. 


\section{Acknowledgements}

I wish to thank the three peer-reviewers for their valuable feedback and suggestions, and pointing out mistakes in previous versions of the manuscript. I also thank Marta Lorenzon, Raimo Hakola, and Ulla Tervahauta for engaging discussions on the topic. The research for this article was made possible thanks to the Centre of Excellence in Changes in Sacred Texts and Traditions and the Centre of Excellence in Ancient Near Eastern Empires, both at the University of Helsinki.

\section{Bibliography}

Adler, E. N. 1930. Jewish Travellers in the Middle Ages: 19 Firsthand Accounts. London: Routledge.

Almbladh, K. 2010. The 'Basmala' in Medieval Letters in Arabic Written by Jews and Christians. Orientalia Suecana 59:45-60.

Amitai-Preiss, N. 1997. Arabic Inscriptions, Graffiti and Games. In The Roman Baths of Hammath Gader. Final Report, ed. Y. Hirschfeld, 267-78. Jerusalem: Israel Exploration Society.

Arubas, B. Y. forthcoming. The Arbel Synagogue: A Distinctive Case for the Study of the Evolution of an Assembly-House in the Jewish Galilean Rural Community. In Ancient Synagogues Revealed (New Edition), ed. L. I. Levine, Z. Weiss and U. Leibner. Jerusalem: Israel Exploration Society.

Atkinson, E. 1878. Note on the Ancient Synagogue at Meiron. Palestine Exploration Quarterly 10:24-27.

Avery-Peck, A. J., and J. Neusner, eds. 2001. Judaism in Late Antiquity 3. Where We Stand: Issues \& Debates in Ancient Judaism. Vol. 4: The Special Problem of the Synagogue. 
Leiden: Brill.

Aviam, M. 2019. The Ancient Synagogues in Galilee. Early Christianity 10:292-314.

Avigad, N. 1967. On the Form of Ancient Synagogues in Galilee. In All the Land of Naphtali, ed. J. W. Hirschberg, 91-100. Jerusalem: Israel Exploration Society.

Avner, R. 2006-2007. The Kathisma: A Christian and Muslim Pilgrimage Site. ARAM 1819:541-57.

Avni, G. 2014. The Byzantine-Islamic Transition in Palestine: An Archaeological Approach. Oxford: Oxford University Press.

Bailey, G. 2007. Time Perspectives, Palimpsests and the Archaeology of Time. Journal of Anthropological Archaeology 26:198-223.

Bender, B. 1998. Stonehenge: Making Space. Oxford: Berg.

Bernbeck, R. 2019. 'Squatting' in the Iron Age: An Example of Third Space in Archaeology. ETopoi. Journal for Ancient Studies 8. http://journal.topoi.org/index.php/etopoi/article/view/287.

Bonar, A. A., and R. M. M'Cheyne. 1849. Narrative of a Mission of Inquiry to the Jews from the Church of Scotland in 1839. Edinburgh: Whyte \& Co.

Bonnie, R. 2016. Thrown into Limekilns. The Reuse of Statuary and Architecture in Galilee from Late Antiquity Onwards. In Spaces in Late Antiquity: Cultural, Theological and Archaeological Perspectives, ed. J. Day et al., 190-211. London: Routledge.

Bonnie, R. 2019. Being Jewish in Galilee, 100-200 CE: An Archaeological Study. Studies in Eastern Mediterranean Archaeology 11. Turnhout: Brepols.

Bonnie, R., R. Hakola, and U. Tervahauta, eds. 2020. The Synagogue in Ancient Palestine: Current Issues and Emerging Trends. Forschungen zur Religion und Literatur des Alten und Neuen Testament 279. Göttingen: Vandenhoeck \& Ruprecht.

Britt, K. C., and R. Boustan. 2017. The Elephant Mosaic Panel in the Synagogue at Huqoq: 
Official Publication and Initial Interpretations. Journal of Roman Archaeology

Supplements 106. Portsmouth, RI: Journal of Roman Archaeology.

Callegher, B. 1997. Un Ripostiglio Di Monete d'Oro Bizantine Dalla Sinagoga Di Cafarnao. Liber Annuus 47:329-38.

Callegher, B. 2007. Cafarnao IX. Monete Dall'Urbana Di Cafarnao (1968-2003). SBF

Collectio Maior 47. Jerusalem: Franciscan Printing Press.

Corbo, V. 1975. Cafarnao I. Gli Edifici Della Citta'. SBF Collectio Maior 19. Jerusalem: Franciscan Printing Press.

Cytryn-Silverman, K. 2015. Tiberias, From Its Foundation to the End of the Early Islamic Period. In Galilee in the Late Second Temple and Mishnaic Periods, Vol. 2: The Archaeological Record from Cities, Towns, and Villages, ed. D. A. Fiensy and J. R. Strange, 186-210. Minneapolis: Fortress.

Donner, F. M. 2010. Muhammad and the Believers: At the Origins of Islam. Cambridge, MA: Belknap Press.

Evans, H. C., and B. Ratliff, eds. 2012. Byzantium and Islam: Age of Transition, 7th-9th Century. New York: Metropolitan Museum of Art.

Gil, M.. 1992. A History of Palestine, 634-1099. Cambridge: Cambridge University Press. Gosden, C., and Y. Marshall. 1999. The Cultural Biography of Objects. World Archaeology 31:169-78.

Grabar, O., and B. Z. Kedar, eds. 2009. Where Heaven and Earth Meet: Jerusalem's Sacred Esplanade. Jamal and Rania Daniel Series in Contemporary History, Politics, Culture and Religion of the Levant. Jerusalem: Yad Ben-Zvi Press.

Hachlili, R. 2013. Ancient Synagogues - Archaeology and Art: New Discoveries and Current Research. Handbook of Oriental Studies 1.105. Leiden: Brill.

Hakola, R, R. Bonnie, and U. Tervahauta. 2020. “The Synagogue in Ancient Palestine: 
Current Issues and Emerging Trends." In The Synagogue in Ancient Palestine:

Current Issues and Emerging Trends, ed. R. Bonnie, R. Hakola and U. Tervahauta, 7-

36. Forschungen zur Religion und Literatur des Alten und Neuen Testament 279.

Göttingen: Vandenhoeck \& Ruprecht.

Halevy, D. 2018. Toward a Palestinian History of Ruins: Interwar Gaza. Journal of Palestinian Studies 48:53-72.

Hamilakis, Y. 2007. The Nation and Its Ruins: Antiquity, Archaeology, and National Imagination in Greece. Oxford: Oxford University Press.

Hamilakis, Y. 2013. Archaeology and the Senses: Human Experience, Memory, and Affect. Cambridge: Cambridge University Press.

Hanson, R. S. 1980. Tyrian Influence in Upper Galilee. Meiron Excavation Project Report 2. Cambridge, MA: American Schools of Oriental Research.

Harvey, D. C. 2003. 'National' Identities and the Politics of Ancient Heritage: Continuity and Change at Ancient Monuments in Britain and Ireland, c.1675-1850. Transactions of the Institute of British Geographers 28:473-87.

Holtorf, C. 2002. Notes on the Life History of a Pot Sherd. Journal of Material Culture 7:4971.

Holtorf, C. 2015. What Future for the Life-History Approach to Prehistoric Monuments in the Landscape. In Landscape Biographies: Geographical, Historical and Archaeological Perspectives on the Production and Transmission of Landscapes, ed. J. Kolen and H. Renes, 167-82. Amsterdam: Amsterdam University Press.

Ilan, Z., and E. Damati. 1989. The Synagogue at Meroth: Does It Fix Israel's Northern Border in Second Temple Times? Biblical Archaeology Review 15:20-36.

Ilan, Z., and A. Izdarechet. 1993. Arbel. New Encyclopedia of Archaeological Excavations in the Holy Land 1:87-89. 
Jacobs, M. 2014. Reorienting the East: Jewish Travelers to the Medieval Muslim World. Philadelphia: University of Pennsylvania Press.

Jones, A. M. 2007. Memory and Material Culture. Cambridge: Cambridge University Press.

Joy, J. 2009. Reinvigorating Object Biography: Reproducing the Drama of Object Lives. World Archaeology 41:540-56.

Joyce, R., and S. D. Gillespie. 2015. Making Things out of Objects That Move. In Things in Motion: Object Itineraries in Anthropological Practice, ed. R. Joyce and S. D. Gillespie, 3-20. Santa Fe, NM: School for Advanced Research Press.

Khalek, N. 2011. Damascus after the Muslim Conquest: Text and Image in Early Islam. Oxford: Oxford University Press.

Khalidi, W. 1992. All That Remains: The Palestinian Villages Occupied and Depopulated by Israel in 1948. Washington, DC: Institute for Palestine Studies.

Kohl, H., and C. Watzinger. 1916. Antike Synagogen in Galilaea. Leipzig: Hinrichs. Kopytoff, I. 1986. The Cultural Biography of Things: Commoditization as Process. In The Social Life of Things: Commodities in Cultural Perspective, ed. A. Appadurai, 64-91. Cambridge: Cambridge University Press.

Lapin, H. 2017. Population Contraction in Late Roman Galilee: Reconsidering the Evidence. BASOR 378:127-43.

Leibner, U. 2009a. Settlement and History in Hellenistic, Roman and Byzantine Galilee: An Archaeological Survey of the Eastern Galilee. Texts and Studies in Ancient Judaism 127. Tübingen: Mohr Siebeck.

Leibner, U. 2009b. Settlement Patterns in the Eastern Galilee: Implications Regarding the Transformation of Rabbinic Culture in Late Antiquity. In Jewish Identities in Antiquity. Studies in Memory of Menahem Stern, ed. L. I. Levine and D. R. Schwartz, 269-95. Tübingen: Mohr Siebeck. 
Levine, L. I. 2005. The Ancient Synagogue. The First Thousand Years. 2nd ed. New Haven, CT: Yale University Press.

Levine, L. I. 2013. Visual Judaism in Late Antiquity: Historical Contexts of Jewish Art. New Haven, CT: Yale University Press.

Levy-Rubin, M. 2011. Non-Muslims in the Early Islamic Empire: From Surrender to Coexistence. Cambridge: Cambridge University Press.

Lewis, B. 1953. An Arabic Account of the Province of Safed-I. Bulletin of the School of Oriental and African Studies 15:477-88.

Lissovsky, N. 2008. Hukkok, Yaquq and Habakkuk's Tomb: Changes over Time and Space. Palestinian Exploration Quarterly 140:103-18.

Loffreda, S. 1985. Recovering Capharnaum. SBF Guides 1. Jerusalem: Edizioni Custodia Terra Santa.

Loffreda, S. 1993. Capernaum. New Encyclopedia of Archaeological Excavations in the Holy Land 1:291-95.

Lucas, G. 2005. The Archaeology of Time. London: Routledge.

Lucas, G. 2008. Time and the Archaeological Event. Cambridge Archaeological Journal $18: 57-59$.

Lucas, G. 2016. Building Lives. In Elements of Architecture: Assembling Archaeology, Atmosphere and the Performance of Building Spaces, ed. M Bille and T. F. Sørensen, 123-38. Archaeological Orientations. London: Routledge.

Magness, J. 1997. "The Chronology of Capernaum in the Early Islamic Period.” Journal of the American Oriental Society 117:481-86.

Magness, J. 2001. The Question of the Synagogue: The Problem of Typology. In Judaism in Late Antiquity 3. Where We Stand: Issues \& Debates in Ancient Judaism. Vol. 4: The Special Problem of the Synagogue, ed. A. J. Avery-Peck and J. Neusner, 1-48. 
Leiden: Brill.

Magness, J. 2003. The Archaeology of the Early Islamic Settlement in Palestine. Winona Lake, IN: Eisenbrauns.

Magness, J. 2010. The Ancient Synagogue at Nabratein. Bulletin of the American Schools for Oriental Research 358:61-68.

Magness, J., S. Kisilevitz, K. Britt, M. J. Grey, and C. S. Spigel. 2014. Huqoq (Lower Galilee) and Its Synagogue Mosaics: Preliminary Report on the Excavations of 201113. Journal of Roman Archaeology 27:327-55.

Magness, J., S. Kisilevitz, M. J. Grey, D. Mizzi, J. Burney, K. Britt, and R. Boustan. 2020. Huqoq - 2019. Hadashot Arkheologiyot - Excavations and Surveys in Israel 132. https://www.hadashot-esi.org.il/report_detail_eng.aspx?id=25880.

Magness, J., S. Kisilevitz, M. J. Grey, D. Mizzi, D. Schindler, M. Wells, K. Britt, R. Boustan, S. O’Connell, E. Hubbard, J. George, J. Ramsay, E. Boaretto, M. Chazan. 2018. The Huqoq Excavation Project: 2014-2017 Interim Report.” Bulletin of the American Schools for Oriental Research 380:61-131.

Magness, J., and D. Schindler. 2015. Pottery and Jewish Settlement in Late Roman Galilee. Bulletin of the American Schools for Oriental Research 374:191-207.

Meri, J. W. 2002. The Cult of Saints among Muslims and Jews in Medieval Syria. Oxford Oriental Monographs. Oxford: Oxford University Press.

Meyers, E. M. 2001. The Dating of the Gush Halav Synagogue: A Response to Jodi Magness. In Judaism in Late Antiquity 3. Where We Stand: Issues \& Debates in Ancient Judaism. Vol. 4: The Special Problem of the Synagogue, ed. A. J. Avery-Peck and J. Neusner, 49-70. Leiden: Brill.

Meyers, E. M., and C. L. Meyers. 2009. Excavations at Ancient Nabratein: Synagogue and Environs. Meiron Excavation Project Report 6. Winona Lake, IN: Eisenbrauns. 
Meyers, E. M., C. L. Meyers, and J. F. Strange. 1990. Excavations at the Ancient Synagogue of Gush Halav. Meiron Excavation Project Report 5. Winona Lake: Eisenbrauns.

Meyers, E. M., J. F. Strange, and C. L. Meyers. 1981. Excavations at Ancient Meiron, Upper Galilee, Israel, 1971-72, 1974-75, 1977. Meiron Excavation Project Report 3. Cambridge, MA: American Schools of Oriental Research.

Nees, L. 2016. Perspectives on Early Islamic Art in Jerusalem. Arts and Archaeology of the Islamic World 5. Leiden: Brill.

Olivier, L. 2004. The Past of the Present. Archaeological Memory and Time. Archaeological Dialogues 10:204-13.

Olivier, L. 2008. Le Sombre Abîme Du Temps. Mémoire et Archéologie. Paris: Seuil.

Penn, M. P. 2015. Envisioning Islam: Syriac Christians and the Early Muslim World. Divinations: Rereading Late Ancient Religions. Philadelphia: University of Pennsylvania Press.

Pluciennik, M. 1999. Archaeological Narratives and Other Ways of Telling. Current Anthropology 40:653-78.

Pococke, R. 1743. A Description of the East, and Some Other Countries. Vol. 2. London: W. Bowyer.

Rattenborg, R., and L. Blanke. 2017. Jarash in the Islamic Ages (c. 700-1200 CE): A Critical Review. Levant 49:312-32.

Renard, J. 2020. Crossing Confessional Boundaries: Exemplary Lives in Jewish, Christian, and Islamic Traditions. Oakland, CA: University of California Press.

Robinson, E. 1856. Later Biblical Researches in Palestine and in the Adjacent Regions a Journal of Travels in the Year 1852. London: Murray.

Schick, R. 1995. The Christian Communities of Palestine from Byzantine to Islamic Rule: A Historical and Archaeological Study. Princeton: Darwin Press. 
Sebanne, M. 2000. Two Game Boards. In Ramat Hanadiv Excavations: Final Report of the 1984-1998 Seasons, ed. Y. Hirschfeld, 226-31. Jerusalem: Israel Exploration Society.

Sirry, M. 2011. The Public Role of Dhimmīs during 'Abbāsid Times. Bulletin of the School of Oriental and African Studies 74:187-204.

Smithline, H. 2015. Meron: A Late Roman-Ottoman Settlement. 'Atiqot 83:125-42.

Spigel, C. S. 2012. Ancient Synagogue Seating Capacities: Methodology, Analysis and Limits. Texts and Studies in Ancient Judaism 149. Tübingen: Mohr Siebeck.

Spigel, C. S. 2016. Debating Ancient Synagogue Dating: The Implications of Deteriorating Data. Bulletin of the American Schools for Oriental Research 376:83-100.

Spijkerman, A. 1975. Cafarnao III. Catalogo Delle Monete Della Citta'. SBF Collectio Maior 19. Jerusalem: Franciscan Printing Press.

Stern, K. B. 2016. Harnessing the Sacred: Hidden Writing and 'Private' Spaces in Levantine Synagogues. In Inscriptions in the Private Sphere in the Greco-Roman World, ed. R. Benefiel and P. Keegan, 213-47. Brill Studies in Greek and Roman Epigraphy 7. Leiden: Brill.

Stern, K. B. 2018. Writing on the Wall: Graffiti and the Forgotten Jews of Antiquity. Princeton: Princeton University Press.

Stern, K. B. 2019. Memory, Postmemory, and Place in the Synagogues of Roman Syria. Bulletin of the Institute of Classical Studies 62:53-85.

Stern, K. B. 2020. Prayer as Power. Amulets, Graffiti, and Vernacular Writing in Ancient Levantine Synagogues. In The Synagogue in Ancient Palestine: Current Issues and Emerging Trends, ed. R. Bonnie, R. Hakola and U. Tervahauta, 221-46. Forschungen zur Religion und Literatur des Alten und Neuen Testaments 279. Göttingen: Vandenhoeck \& Ruprecht.

Syon, D. 2015. Small Change in Hellenistic-Roman Galilee. Numismatic Site Finds as a Tool 
for Historical Reconstruction. Jerusalem: Israel Numismatic Society.

Tarkhanova, S. 2020. The Friezes with the 'Peopled Scrolls' Motif in the Capernaum

Synagogue: Dating by Stylistic Method and Some Aspects of the Reconstruction. In

The Synagogue in Ancient Palestine: Current Issues and Emerging Trends, ed. R.

Bonnie, R. Hakola and U. Tervahauta, 195-218. Forschungen zur Religion und

Literatur des Alten und Neuen Testaments 279. Göttingen: Vandenhoeck \& Ruprecht.

Taxel, I. 2018. Early Islamic Palestine: Toward a More Fine-Tuned Recognition of

Settlement Patterns and Land Uses in Town and Country. Journal of Islamic Archaeology 5:153-80.

Thomson, W. M. 1860. The Land and the Book, or Biblical Illustrations Drawn from the Manners and Customs, the Scenes and Scenery of the Holy Land. London: Nelson and Sons.

Tsafrir, Y., and G. Foerster. 1992. The Dating of the 'Earthquake of the Sabbatical Year' of 749 C.E. in Palestine. Bulletin of the School of Oriental and African Studies 55:23135.

Tzaferis, V. 1989. Excavations at Capernaum, 1978-1982. Winona Lake, IN: Eisenbrauns. van de Velde, C. W. M. 1854. Narrative of a Journey Through Syria and Palestine in 1851 and 1852. Edinburgh: W. Blackwood and sons.

Walmsley, A. G. 2007. Early Islamic Syria: An Archaeological Assessment. Duckworth Debates in Archaeology. London: Duckworth.

Watkin, D. 2009. The Roman Forum. Cambridge, MA: Harvard University Press.

Werlin, S. H. 2015. Ancient Synagogues of Southern Palestine, 300-800 C.E.: Living on the Edge. The Brill Reference Library to Judaism 47. Leiden: Brill.

Wilson, C. W. 1881. Picturesque Palestine, Sinai and Egypt. Vol. 2. London: Virtue \& Co.

Yalouri, E. 2001. The Acropolis: Global Fame, Local Claim. Oxford: Berg. 
Yazbak, M. 2010. Holy Shrines (Maqamat) in Modern Palestine/Israel and the Politics of Memory. In Holy Places in the Israeli-Palestinian Conflict : Confrontation and CoExistence, ed. M. J. Breger, Y. Reiter and L. Hammer, 231-48. London: Routledge. Yuval-Hacham, N. 2014. Mishnah Avodah Zarah 4:5 - The Faces of Effacement: Between Textual and Artistic Evidence. In Talmuda De-Eretz Israel: Archaeology and the Rabbis in Late Antique Palestine, ed. S. Fine and A. Koller, 29-52. Studia Judaica 73. Berlin: De Gruyter. 